\title{
L-Glutamate-Induced Responses and CGMP-Activated Channels in Three Subtypes of Retinal Bipolar Cells Dissociated from the Cat
}

\author{
Pedro de la Villa, ${ }^{1,2}$ Takashi Kurahashi, ${ }^{1}$ and Akimichi Kaneko ${ }^{1, a}$ \\ 'Department of Information Physiology, National Institute for Physiological Sciences, Okazaki 444, Japan and \\ ${ }^{2}$ Department of Physiology and Pharmacology, University of Alcalá de Henares, Madrid, Spain
}

\begin{abstract}
Effects of L-glutamate (Glu), the neurotransmitter released by photoreceptors, on isolated cat bipolar cells were examined. Membrane currents of bipolar cells were recorded by the patch-clamp technique in a conventional whole-cell recording configuration using pipettes containing $1 \mathrm{~mm}$ cGMP, which has been known to activate a cationic current sensitive to Glu in ON-type bipolar cells. ON-type bipolar cells (depolarized by light in in situ) and OFF-type bipolar cells (hyperpolarized by light) were identified by their response polarity to Glu. When the whole-cell configuration was established, ON-type bipolar cells showed a steady inward current which was suppressed by Glu, consistent with the response polarity observed in in situ recordings. In contrast, OFF-type cells did not show a steady current during the recordings. However, they responded to Glu with an increase in cationic conductance. Among recorded cells, rod-driven bipolar cells were identified by their immunoreactivity to anti-protein kinase C (PKC-IR) antibody. Examination of PKC-IR revealed that ON-type bipolar cells included both rod- and cone-driven bipolar cells, while OFF-type cells were all cone-driven bipolar cells.

The cGMP-activated current observed in ON-type cells was accompanied by a change in the current fluctuation due to the opening and closing of underlying channels. Fluctuation analysis gave a unitary conductance value of $13 \mathrm{pS}$. In half of the cells examined, maximum open probability reached almost $100 \%$. The cGMP-activated channel in bipolar cells seems novel, fundamentally different from those found in photoreceptor cells or olfactory receptor cells.
\end{abstract}

[Key words: bipolar cell, L-glutamate, photoreceptor cell, olfactory receptor cell, cGMP-activated channel, cat]

In the visual system the light signal received by photoreceptors is carried by ON and OFF pathways to higher centers. Lightinduced responses in photoreceptors are all hyperpolarizing, and

\footnotetext{
Received Aug. 15, 1994; revised Oct. 31, 1994; accepted Nov. 28, 1994.

We thank Drs. G. H. Gold, G. Lowe, and J. Stocker for critical reading of the manuscript, and H. Akita, F. Mizutani, and Y. Ito for their technical assistance. This work was supported in part by Grants-in-Aid for Scientific Research from the Ministry of Education, Science and Culture (04454140, 04557006 , and 04267220) and by Human Frontier Science Program Grant (A.K.). P.V. was supported by a Fellowship of the Japan Society for Promotion of Science.

Correspondence should be addressed to Dr. Akimichi Kancko, Department of Physiology, Keio University School of Medicine, Shinjuku, Tokyo 160, Japan.

:Present address: Department of Physiology, Keio University School of Medicine, Shinjuku, Tokyo 160, Japan.

Copyright 1995 Society for Neuroscience 0270-6474/95/153571-12\$05.00/0
}

it is the bipolar cell where the visual signal is encoded into ON and OFF signals. Generation of depolarizing and hyperpolarizing responses in bipolar cells to the transmitter released from photoreceptors has been assumed to be due to different mechanisms underlying photoreceptor-bipolar synapse. In the axolotl (Attwell et al., 1987) and rat (Yamashita and Wässle, 1991) it has been shown that ON-type bipolar cells respond to L-glutamate (Glu), the transmitter released from photoreceptors (Ayoub et al., 1989; Copenhagen and Jahr, 1989), with a decrease in cationic conductance. This mechanism explains a membrane depolarization in response to light which causes a reduction of Glu release from photoreceptors. An increase in $\mathrm{K}$ conductance by Glu has been proposed as an alternative mechanism for Gluinduced hyperpolarization in isolated bipolar cells of the tiger salamander (Hirano and MacLeish, 1990), but its contribution to the response generation is still controversial. In contrast, OFFtype bipolar cells respond to Glu with an increase in membrane conductance to cations (Attwell et al., 1987; Hirano and MacLeish, 1990; Gilbertson et al., 1991).

Recently, it has been demonstrated in amphibians and fish that the Glu-suppressed channels in ON-type bipolar cells are cationic channels activated by cytoplasmic cGMP (Nawy and Jahr, 1990a; Shiells and Falk, 1990, 1992ab). Because of their sen sitivities to cytoplasmic cGMP, it has been hypothesized that the cGMP-activated channel found in bipolar cells belongs to the same family of channels mediating the phototransduction (Fesenko et al., 1985) or olfactory transduction (Nakamura and Gold, 1987). We report here, however, that the cGMP-activated channels of bipolar cells are fundamentally different from those of sensory transduction channels. Our findings agree with earlier noise analysis data on Glu-suppressive current in axolotl bipolar cells ( $\Lambda$ ttwell et al., 1987; Wilson et al., 1987). It is highly likely that the cGMP-activated channel in bipolar cells is a novel subtype among cyclic nucleotide-gated channels.

In the mammalian retina, rods and cones drive a separate set of bipolar cells, while in many lower vertebrates bipolar cells receive mixed rod and cone inputs. In the present work we studied cat bipolar cells to examine the rod- and cone-driven synapses separately. Based on morphological characteristics it has been assumed that rod-driven bipolar cells are all ON-type cells and cone-driven bipolar cells are both $\mathrm{ON}$ - and OFF-types (Nelson et al., 1978), but electrophysiological experiments on mammalian bipolar cells in situ are extremely difficult. Recently it has been reported that rod bipolar cells exclusively show a strong protein kinase C-like immunoreactivity (PKC-IR) (Negishi et al., 1988; Greferath et al., 1990; Suzuki and Kaneko, 1991). We aimed to learn the similarities and differences of Glu- 
induced responses of three subtypes of cat bipolar cells-rod bipolar cells and cone ON- and OFF-type bipolar cells, by identifying them by PKC-IR. The PKC-IR-positive cells respond to Glu only with a conductance decrease to cations, whereas PKCIR-negative cells show either conductance increase or decrease to cations. The present finding supports the hypothesis that roddriven bipolar cells are all ON type, and cone-driven bipolar cells include both $\mathrm{ON}$ and OFF types.

\section{Materials and Methods}

Enzymatic dissociation. Bipolar cells were enzymatically dissociated from the retina of deeply anesthetized young adult cats. Animals were handled according to the Society for Neuroscience's statement for the use of animals. Cats were dark adapted for about $20 \mathrm{~min}$ prior to death. This procedure is assumed to make the cat retina easy to remove from the pigment epithelial layer. The cat was anesthetized with diethyl-ether. When the cat reached the deepest stage of anesthesia, it was killed by cervical dislocation. Dissected cycballs wcre hemisceted, and the retinac were detached from the pigment epithelium and incubated for 50-60 min in a Ringer solution (in mM $135 \mathrm{NaCl}, 5 \mathrm{KCl}, 1 \mathrm{MgCl}_{2}, 1 \mathrm{CaCl}_{2}$, 10 HEPES, 10 glucose, pH adjusted to 7.4 with $\mathrm{NaOH}$ ) containing 2 $\mathrm{U} / \mathrm{ml}$ papain (Worthington, Freehold, NJ) and $0.1 \mathrm{mg} / \mathrm{ml}$ cysteine at $30^{\circ} \mathrm{C}$. The retinae were triturated mechanically by pipetting. Dissociated cells were seeded in a culture dish containing $3 \mathrm{ml}$ Ringer solution. The bottom of the culture dish was made of a cover glass coated with concanavalin-A by the following procedure. A drop of concanavalin-A (Sigma, C2010) solution $(0.1 \mathrm{mg} / \mathrm{ml}$ of $1 \mathrm{M} \mathrm{NaCl}$ ) was placed on the cover glass for $20 \mathrm{~min}$, after which the dish was washed with distilled water three times. The dish was air dried and used. Dissociation yielded a mixture of cells, but bipolar cells were identified unequivocally from other retinal cells by their characteristic morphology (see Fig. 1). Cells were stored at $4^{\circ} \mathrm{C}$ for $2-12 \mathrm{hr}$ before recording.

Recording procedure. For recording, the culture dish was mounted on the stage of an inverted microscope with phase-contrast or Nomarski uptics (Nikon, TMD). Cells were recorded using the patch-clamp technique in the whole-cell configuration (Hamill et al., 1981). The pipette was connected to a patch-clamp amplifier (List Electronics, Darmstadt, Germany, L/M EPC-7). An Ag-AgCl indifferent electrode was connected to the superfusate via an agarose bridge $(120 \mathrm{~mm} \mathrm{NaCl}, 1 \%$ Agar). Membrane potentials were specified by a personal computer (PC$9801 \mathrm{VX}, \mathrm{NEC}$, Tokyo) with a programmable 12-bit D/A converter. Time and voltage resolutions of the pulse generator were $0.5 \mathrm{msec}$ and $0.1 \mathrm{mV}$, respectively. Data were sampled and digitized by a 12-bit A/D converter after passing through an eight-pole Bessel filter (Model FV625A, NF Circuit Design Block Co. Ltd., Yokohama). For noise analysis, the data were recorded on a videotape after passing through a PCM processor (frequency range, $0-15 \mathrm{kHz}$ ), and the data from the videotape was sampled with a microcomputer with a sampling frequency of $1-5$ $\mathrm{kH} z$ after passing through an eight-pole Butterworth filter. The cutoff frequency of the filter was set to one-half of the sampling frequency to minimize aliasing. The junction potential at the pipette tip was neglected because it was small under the present conditions $(<3 \mathrm{mV}$, Kaneko and Tachibana, 1986). In ion substitution experiments, the junction potential at the indifferent electrode was compensated for by a method described elsewhere (Kaneko and Tachibana, 1986). Sampled data were analyzed by an off-line PC98 microcomputer (NEC, Japan) or VAX station 3100 (Digital Equipment Corp., Maynard, MA) with laboratory-made programs. Recordings were made at room temperature.

The pipette solution contained (in mM) $120 \mathrm{CsCl}, 1 \mathrm{MgCl}_{2}, 5$ EGTA, $0.5 \mathrm{CaCl}_{2}$, and 10 HEPES ( $\mathrm{pH}$ adjusted to 7.2 with $\mathrm{CsOH}$ ). Unless otherwise indicated, cGMP (1 mM) and GTP ( $1 \mathrm{~mm}$ ) were added to the pipette solution in order to monitor the current sensitive to cytoplasmic cGMP (Nawy and Jaltr, 1990a) which is regulated by a G-protein-Inediated cascade (Nawy and Jahr, 1990a, 1991; Shiells and Falk, 1990). High internal Cs was used in order to suppress potassium currents through voltage-activated channels ( $P$. de la Villa and $A$. Kaneko, unpublished observations), which enabled us to specify the reversal potential of cGMP-sensitive current. After breakthrough to whole-cell recording configuration, we waited until the potassium currents were suppressed by diffusion of $\mathrm{Cs}$ from the pipette. It took approximately $30 \mathrm{sec}$, during which we applied test command voltage pulses, to check the K-current and to confirm rupture of the patch membrane. Pipettes were made of Pyrex tubing $(1.2 \mathrm{~mm}$ o.d.) pulled in two steps on a pipette puller (Narishige Scientific Instruments, PP-83). After heat polishing, the inner diameter of the pipette was about $1 \mu \mathrm{m}(5-10 \mathrm{M} \Omega$ in the bath). In order to minimize the stray capacitance of the electrode, the external wall of the pipette was coated with an insulating resin (Apiezon wax, Apiezon Products Ltd., London) dissolved in chloroform. Residual capacitance of the pipette was electrically compensated.

Perfusion and drug application. Cells were continuously superfused at a rate of $0.6 \mathrm{ml} / \mathrm{min}$ with Ringer solution (see above). Solutions containing various $\left[\mathrm{Na}^{+}\right]_{o}$ were made by replacing $\mathrm{NaCl}$ with equimolar choline chloride and removing other cations $\left(\mathrm{K}^{+}, \mathrm{Ca}^{2+}, \mathrm{Mg}^{2+}\right)$ to make experiments under near bi-ionic conditions. L-glutamate and 2-amino4-phosphonobutyric acid (APB) (both from Sigma) were dissolved in the bath solution and applied by pressure $\left(0.2-0.3 \mathrm{~kg} / \mathrm{cm}^{2}\right)$ from a pipette with a large bore $(5-10 \mu \mathrm{m}$ diameter) located $20-50 \mu \mathrm{m}$ away from the cell. In order to avoid drug lcakage, a weak ncgative pressurc (adjusted to eliminate efflux of the pipette solution) was constantly applied to the inside of the pipette.

Immunocytochemical procedure. Immunoreactivity against a protein kinase $\mathrm{C}$ antibody was examined by a method described previously (Suzuki and Kaneko, 1990). In brief, dissociated cells were fixed in Zamboni's solution for $2 \mathrm{hr}$ at $4^{\circ} \mathrm{C}$. After rinsing with Dulbecco's phosphate buffer solution (PBS) three times, cells were incubated for $48 \mathrm{hr}$ in PBS containing the antibody against PKC (Amersham, UK; clone $\mathrm{MC5}$ ) and $0.3 \%$ Triton $\mathrm{X}-100$ at $4^{\circ} \mathrm{C}$. After rinsing with PBS, they were reacted for $3 \mathrm{hr}$ with biotinylated anti-mouse IgG in PBS containing $0.1 \%$ Triton $X-100$, followed by a $3 \mathrm{hr}$ incubation in the avidin biotin complex prepared by the standard procedure. The peroxidase was developed using 3,3'-diaminobenzidine tetrahydrochloride.

This procedure was also applied on recorded cells. Bipolar cells were photographed immediately after recording under Nomarski optics. The position of the cell in the dish was registered by $\mathrm{X} / \mathrm{Y}$ coordinates of the microscope stage. After processing immunocytochemically, the cells were identified by the registered position of the microscope and photographed. All cells tested remained at the same position after the PKCIR procedure.

\section{Results}

\section{$P K C-I R$ and current response to L-glutamate}

In order to make an objective identification of the subtype of the isolated bipolar cells, we first reacted cells with an anti-PKC antibody which is known to be a reliable marker for the roddriven bipolar cells (Negishi et al., 1988; Greferath et al., 1990; Suzuki and Kaneko, 1991). In our preparation, 110 out of 120 randomly selected isolated bipolar cells $(92 \%)$ showed positive PKC-IR. This fraction of staining is almost identical to a previous experiment (89\%, Suzuki and Kaneko, 1991). The morphological characteristics of cells showing positive PKC-IR were similar to those of the rod bipolar cell in situ (Boycott and Kolb, 1973): a small soma ( $<6 \mu \mathrm{m}$ in diameter), thin and relatively long dendrites ending in fine tips, and a long axon (usually $>15 \mu \mathrm{m}$ ) (Fig. 1A,Ba). Cells that did not show PKC-IR had a morphology slightly different from rod bipolar cells. They had a larger soma (approximately $7-8 \mu \mathrm{m}$ in diameter) and thicker dendrites (Fig. $1 B b, C$ ). The length of the axon was variable. These cells appeared to be cone bipolar cells as identified in morphological reports on cat bipolar cells (Boycott and Kolb, 1973).

Responses to Glu $(100 \mu \mathrm{M})$ were examined in a few hundred cells randonnly selected in the culture dish. Approxinnately half of them showed detectable responses. Of 159 cells that responded to Glu, 147 cells $(92 \%)$ showed an outward current at a holding potential $\left(\mathrm{V}_{\mathrm{h}}\right)$ of $-40 \mathrm{mV}$, the potential close to their resting value (Fig. $1 A, B$, current traces). A minor group of cells (12 cells, $8 \%$ ) responded to Glu with an inward current at the same holding potential. The finding that the majority of bipolar cells showed an outward current to Glu is consistent with the large fraction of rod bipolar cells $(>90 \%)$ in the mammalian 

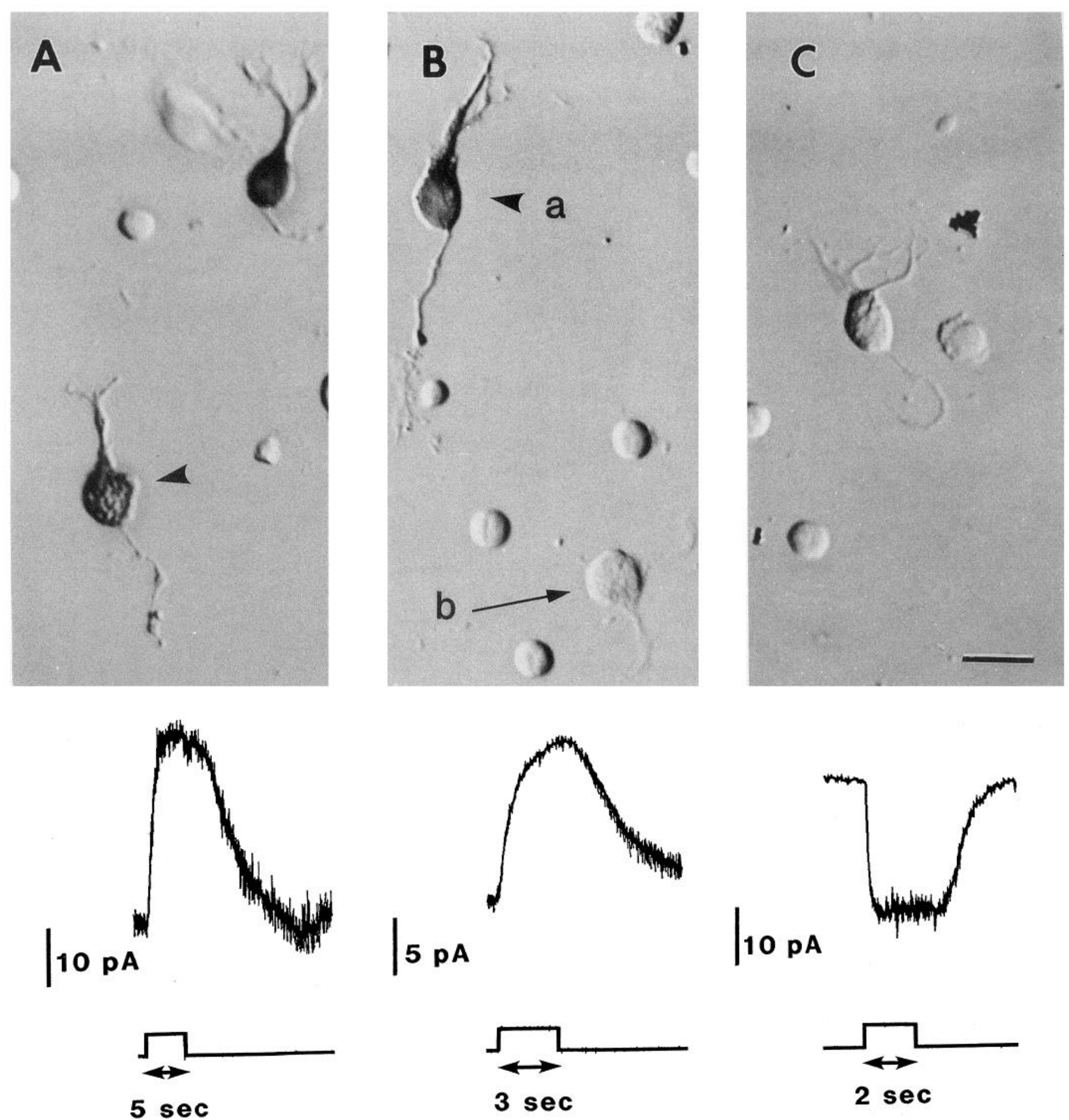

Figure 1. PKC-IR in isolated bipolar cells after recording their Glu-induced responses. A, Two rod bipolar cells showing positive PKC-IR. Outward current (lower panel) was recorded from one of these cells (arrowhead) in response to a $5 \mathrm{sec}$ application of $100 \mu \mathrm{M}$ Glu (marked by an elevation of the bottom trace). B, Outward current (lower panel) was recorded from a cone bipolar cell (showing no PKC-IR, marked $b$ ) in response to a 3 $\mathrm{sec}$ application of $100 \mu \mathrm{M}$ Glu. The cell was somewhat deformed when the patch pipette was removed after recording. Note that a rod bipolar cell in the same dish shows a positive PKC-IR (arrowhead, a). $C$, A cone bipolar cell responding with an inward current to a 2 sec application of 100 $\mu \mathrm{M}$ Glu (lower panel). All cells were voltage clamped at $-40 \mathrm{mV}$. Scale bar, $10 \mu \mathrm{m}$.

retina, since rod bipolar cells are assumed to be all ON-type cells in which Glu is expected to induce an outward current.

The rising time course of the Glu-induced outward current was much slower than that of the Glu-induced inward current (compare current traces shown in Fig. 3A,B). The outward current reached its peak in approximately $1 \mathrm{sec}$. Contrary to the outward current, the rising phase of the inward current was much steeper than that of the outward current. The difference in time courses may be related to the mechanism of response generation of these two types of cells (see Discussion).

To make a direct comparison between the polarity of the Gluinduced response and PKC-IR, we first recorded Glu-induced 
responses and then reacted the recorded cells with the anti-PKC antibody. Since cone bipolar cells are much fewer than rod bipolar cells, we deliberately sampled more cells having a cone bipolar cell-like appearance. All cells showing positive PKCIR, presumably rod bipolar cells, responded with an outward current $(n=15$; see also Fig. $1 A$ ). Of 12 cells which did not show PKC-IR, considered to be cone bipolar cells, Glu induced an outward current in eight cells and an inward current in the four remaining cells. The negative immunoreactivity was not due to a technical failure since we found many other nonrecorded cells in the same dish showing positive PKC-IR (Fig. $1 B)$. No cells showed both positive PKC-IR and an inward current. This result is consistent with the notion that rod bipolar cells are all ON type in the mammalian retina (Dacheux and Raviola, 1986).

\section{Glu-induced outward current}

The Glu-induced outward current described above was actually a reduction of a steady inward current developed after the es- tablishment of the whole-cell patch-clamp condition (Fig. 2). Immediately after the rupture of the patch membrane, the steady inward current was quite small (a few picoamperes in Fig. 2), and the Glu-induced outward current was also very small (Fig. 2 , inset a). The steady inward current increased with time, reaching a maximum value of approximately $50 \mathrm{pA}$ in about $5 \mathrm{~min}$ in this example. (The maximum current amplitude and the time needed to develop the steady current varied from cell to cell.) The amplitude of the Glu-induced outward current increased in proportion to the amplitude of the steady inward current (Fig. 2 , insets b,c), but under no circumstances did the current ever cross the 0 level into the positive direction. The reversal potential of the steady current was near $0 \mathrm{mV}$ and was identical to that of the Glu-suppressed current (see below). When the pipette solution did not contain CGMP, neither development of the steady inward current nor the Glu-induced outward current were detected (five cells; see Discussion). These observations suggest that Glu suppressed the existing current by closing the cGMPactivated channels.
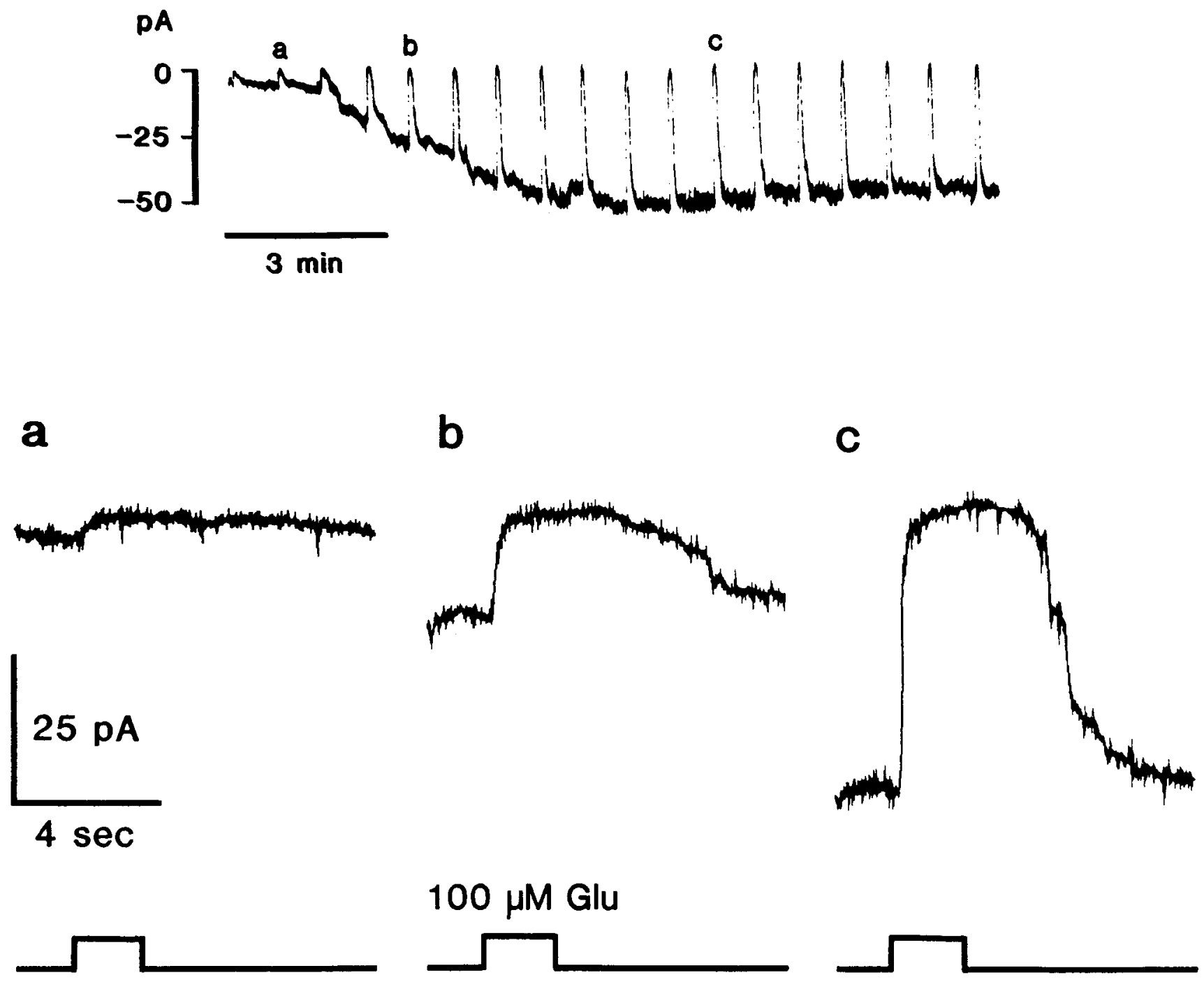

Figure 2. Development of a cGMP-induced inward current in an isolated bipolar cell in which Glu induced an outward current. The continuous trace (top panel) represents the cell response obtained immediately after breaking into the whole-cell configuration $\left(V_{t}=-40 \mathrm{mV}\right.$ ). Upward deflections in the continuous trace represent responses to a $2 \mathrm{sec}$ application of $100 \mu \mathrm{M}$ Glu. Insets $a-c$ illustrate the responses with the same label in the top trace but with an expanded time and current scales. Note that the Glu-induced "outward currents" never exceed the zero current level. Timing of the $100 \mu \mathrm{M}$ Glu application is shown as an elevation of the bottom trace. 
The response amplitude of the Glu-induced outward current (or the cGMP-induced steady inward current) was dependent on the holding voltage; it decreased at more positive holding voltages, almost disappearing near $0 \mathrm{mV}$, and reversed its polarity when the cell was held at voltages more positive than $0 \mathrm{mV}$ (Fig. 3A). The average reversal potential was $0 \pm 5 \mathrm{mV}$ (mean $\pm \mathrm{SD}, n=31$ ). The reversal potential shifted to more negative voltages in low $\left[\mathrm{Na}^{+}\right]_{o} ;-13 \pm 2 \mathrm{mV}$ in $60 \mathrm{~mm}\left[\mathrm{Na}^{+}\right]_{o},-29$ $\pm 4 \mathrm{mV}$ in $30 \mathrm{~mm}\left[\mathrm{Na}^{+}\right]_{o}(n=3)$. The reversal potential and its dependence on $\mathrm{Na}^{+}$indicate that the cGMP-induced steady inward current was carried by ions through nonselective cation channels.

\section{Glu-induced inward current}

As mentioned above, application of Glu induced an inward current in a small population of bipolar cells. In these cells no stcady inward current developed, cven $>10$ min after the establishment of the whole-cell clamp condition with a $1 \mathrm{mM}$ cGMPcontaining pipette. This observation suggests that the Glu-induced inward current was unrelated to the steady inward current evoked in the majority of cells by cytoplasmic cGMP. The amplitude of the Glu-induced inward current varied as a linear function of driving force (difference between the holding voltage and the reversal potential); it became smaller when the holding voltage was shifted to less negative values. The response was almost undetectable at around $0 \mathrm{mV}$, and its polarity reversed at positive holding voltages (Fig. $3 B$ ). The average reversal potential was $0 \pm 5 \mathrm{mV}(n=8)$. We succeeded in measuring the dependence of the reversal potential on $\left[\mathrm{Na}^{+}\right]_{n}$ only in one cell. In this cell the reversal potential shifted to more negative voltages in low $\left[\mathrm{Na}^{+}\right]_{0} ;-14 \mathrm{mV}$ in $60 \mathrm{mM}\left[\mathrm{Na}^{+}\right]_{i}$, and $-28 \mathrm{mV}$ in $30 \mathrm{~mm}\left[\mathrm{Na}^{+}\right]$. The reversal potential and its strong dependence on $\mathrm{Na}^{+}$indicate that the Glu induced inward current is also carried by ions through nonselective cation channels.

\section{Dose-response relationship}

The sensitivity to Glu was examined in cells responding with an outward current (Fig. 4). Since it was difficult to record responses to a series of Glu concentrations in a single cell, we collected data from different cells, each of which was exposed to $100 \mu \mathrm{M}$ Glu and one lower concentration of Glu. Because 100 H.M Glu generated a saturating response, the response to the test concentration was expressed as a fraction of the saturating response. The dose-response relation had a sigmoidal shape with the half-saturating dose of approximately $10 \mu \mathrm{M}$ and a Hill coefficient of 1.3. The dose-response curve shows that the working concentration range of Glu spans approximately from $1 \mu \mathrm{M}$ to $100 \mu \mathrm{M}$, the concentration range reported to be effective for goldfish horizontal cells (Ishida et al., 1984). In the present study, we were unable to examine the dose-response relationship in cells showing Glu-induced inward current because of their small population.

\section{Effect of $A P B$ on bipolar cells identified by $P K C-I R$}

Effect of APB, an agonist for a metabotropic Glu receptor (Slaughter and Miller, 1981), was tested on isolated bipolar cells, the subtypes of which were identified by PKC-IR. We found that cells responding to Glu $(100 \mu \mathrm{M})$ with a reduction of cGMPinduced steady inward current also responded to APB ( $1 \mu \mathrm{M})$ with a reduction of the inward current (seven cells). These included both cells showing positive PKC-IR (four cells, an example shown in Fig. 5A) and cells that did not show positive
PKC-IR (three cells, an example in Fig. 5B). The offset time course of Figure $5 B$ appears slower than that of Figure $5 A$, but this is not a substantial difference (compare also the responses of Fig. $1 A, B$ ). The time courses of the APB-induced and Gluinduced responses were almost identical: an onset delay and a slow rising phase. Both agonists induced similar conductance decrease as revealed by a ramp voltage-clamp method (Fig. 5). The reversal potentials were nearly identical (approximately 0 $\mathrm{mV}$ ).

Bipolar cells which responded to Glu with an inward current did not respond to $1 \mu \mathrm{M}$ APB (Fig. $5 C$ ). Again, the Glu-induced inward current was accompanied by a conductance increase and with an increase in current fluctuations. None of these cells was PKC-IR positive (two cells), consistent with our other observations that cells that exhibited an inward current response were PKC-IR negative.

\section{Estimation of single channel properties of cGMP-activated channels}

Since the inward current activated by cytoplasmic cGMP was accompanied by current fluctuations, we estimated single channel properties by analyzing current fluctuations. We wished to compare channel properties for rod-driven cells and cone-driven cells, but due to technical limitations we were unable to perform cell-type identification by PKC-IR on cells studied by noise analysis. Since the rod bipolar cells occupy the majority, the data presented in this section may represent those obtained from the rod bipolar cells. In five out of 10 cells examined, current fluctuations first increased as the cGMP-activated inward current increased with time and then decreased when the mean amplitude of the inward current further increased and reached a maximum (Fig. 6Aa-Ac). The relation between current fluctuations and the mean amplitude of the cGMP-activated current was also seen during the recovery of the inward current after washout of applied Glu (Fig. 6B). Therefore, the change in current fluctuations is dependent on the mean amplitude of cGMP-activated current and independent of time. Changes in current fluctuations may indicate that in the rising phase of current fluctuations the state of channels shifted from a fully closed state to an openclosed transition, and in the falling phase of current fluctuations opening probability further increased, making most channels open (compare Eqs. 1 and 2 below). In the remaining five cells, current fluctuations increased monotonically with an increase of the mean current amplitude but did not show a decrease until the end of the recording. The reason for the lack of a full opening of the channels remains unclear, but it can be speculated that those cells that were lost before full saturation of cGMP either had a much stronger cGMP buffering capacity or had a higher basal PDE activity that prevented the saturation of intracellular cGMP.

The kinetics of the channel were estimated by calculating the power spectrum distribution (Fig. $6 C$ ). In the absence of external Glu, the power spectrum showed a double Lorentzian function in the range between $1 \mathrm{~Hz}$ and $250 \mathrm{~Hz}$. In the presence of 100 $\mu \mathrm{M}$ Glu, current fluctuations become significantly smaller, as indicated by the reduction of the spectral density level (Fig. $6 \mathrm{Cb}$ ). The power spectrum of the cGMP-activated channel was obtained by subtracting power spectra obtained in the presence of Glu from those obtained in the absence of Glu. The calculated data could be fitted by double Lorentzian functions with corner frequencies of 1.3 and $47 \mathrm{~Hz}$, respectively (Fig. 6Cc). Similar double Lorentzian functions were observed in the power spectra 

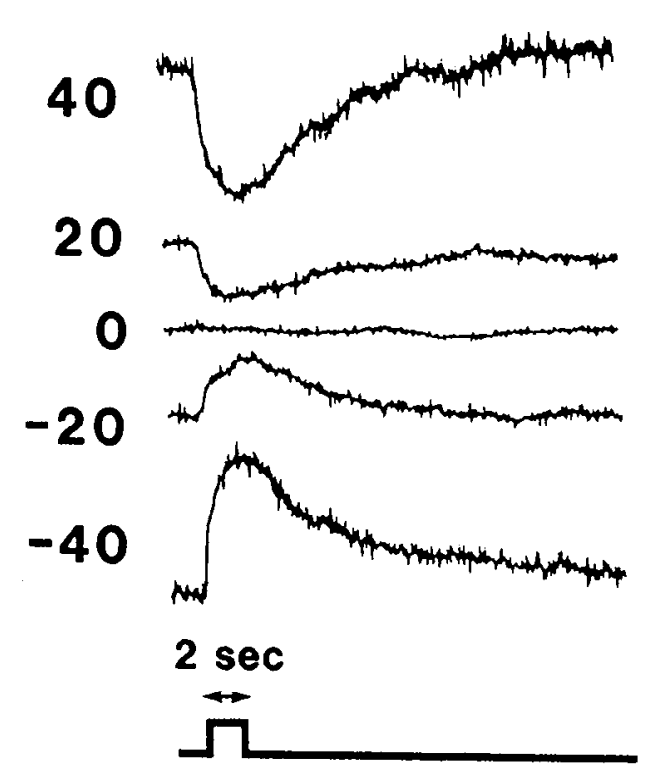

B

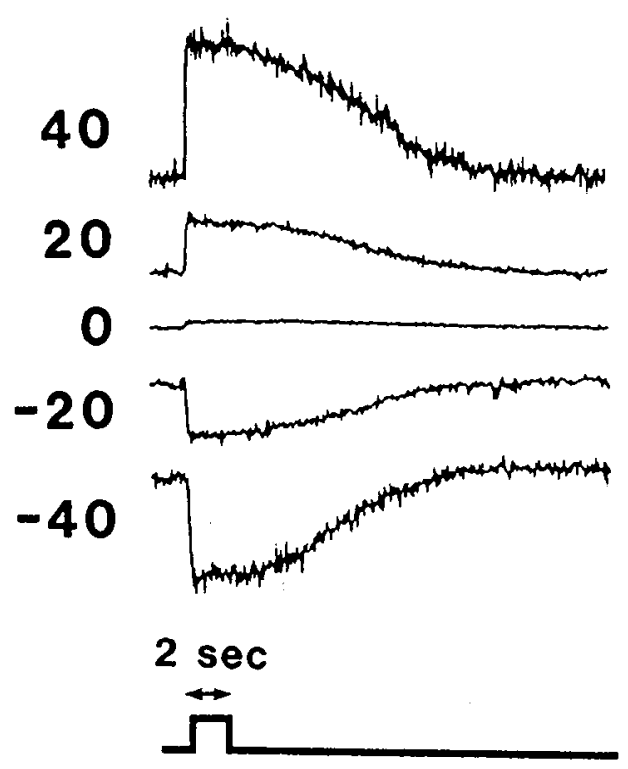

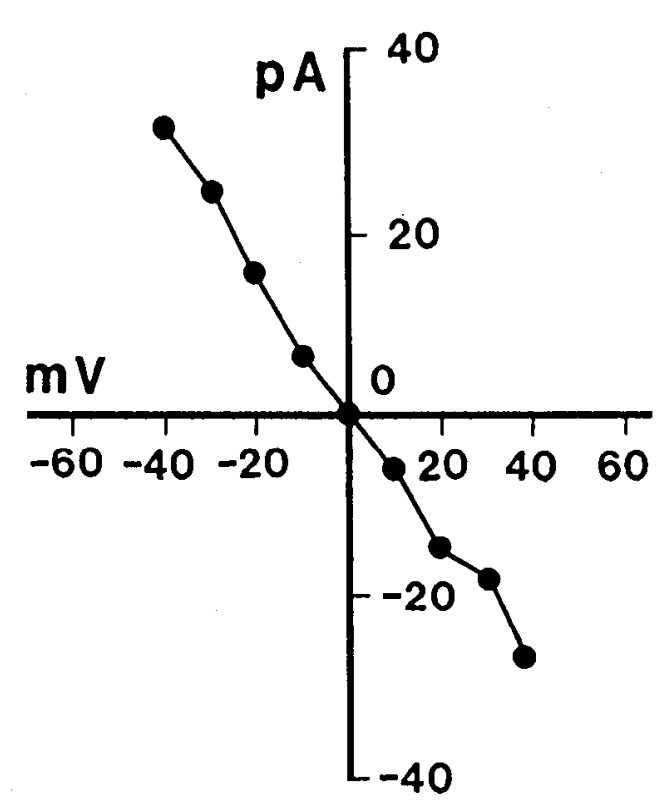

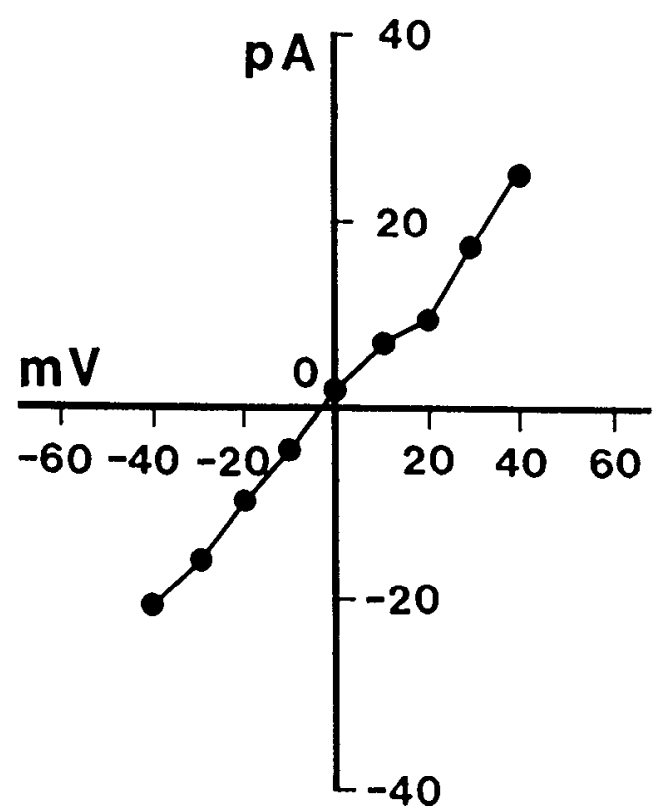

Figure 3. Two types of Glu-induced membrane currents in bipolar cells isolated from the cat retina. $A$, An outward current at negative holding voltages; $B$, an inward current at negative holding voltages (indicated with each current trace). Responses were evoked by 2 sec pressure application of $100 \mu \mathrm{M}$ Glu (marked by an elevation of the bottom traces). Right panels show the current-voltage relation of the Glu-induced responses. The current amplitude was measured at the peak.

of the Glu-sensitive current fluctuations in ON-type bipolar cells of the tiger salamander (Wilson et al., 1987).

Single channel conductance and the number of functioning channels were estimated from the relation between the mean current amplitude $(I)$ and the variance $\left(\sigma^{2}\right)$ (Fig. 7). The relation could be fitted by a parabola, as can be predicted by the following relation (Sigworth, 1980):

$$
\sigma^{2}-i I-I^{2} / N
$$

where $N$ is equal to the total number of cGMP-activated channels and $i$ is the single channel amplitude. Since the variance can be zero when all channels are either closed (open probability, $0 \%$ ) or open (open probability, 100\%), the intercepts between the parabola and the current axis represent $0 \%$ and $100 \%$ 
A
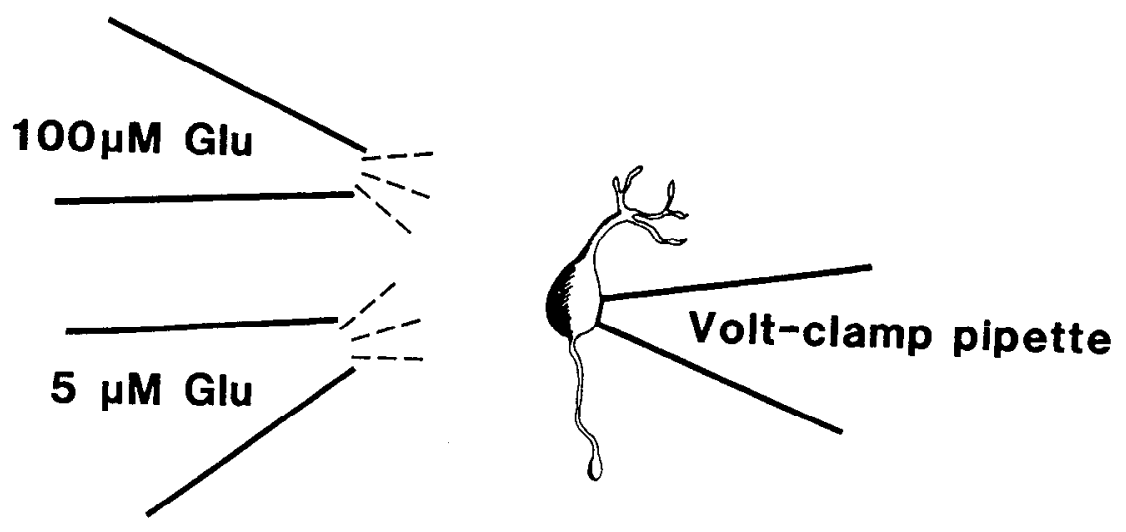

\section{pA $25 \mathrm{sec}$}
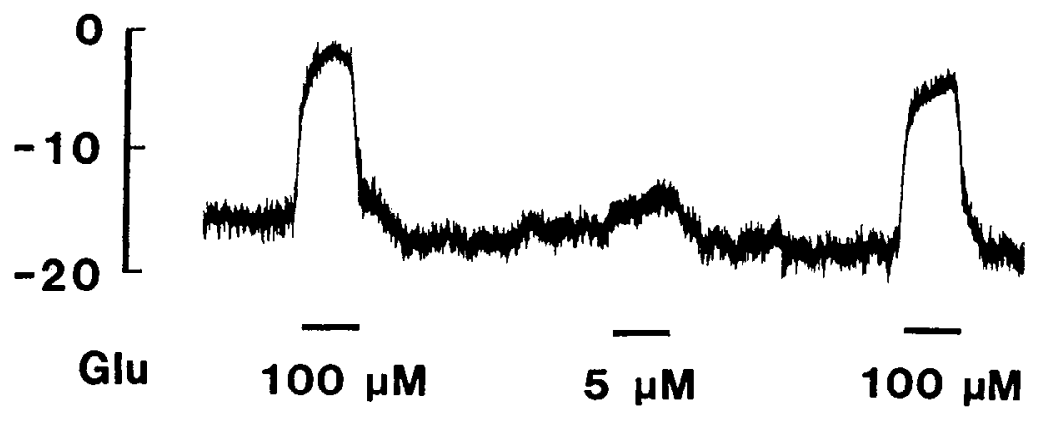

B
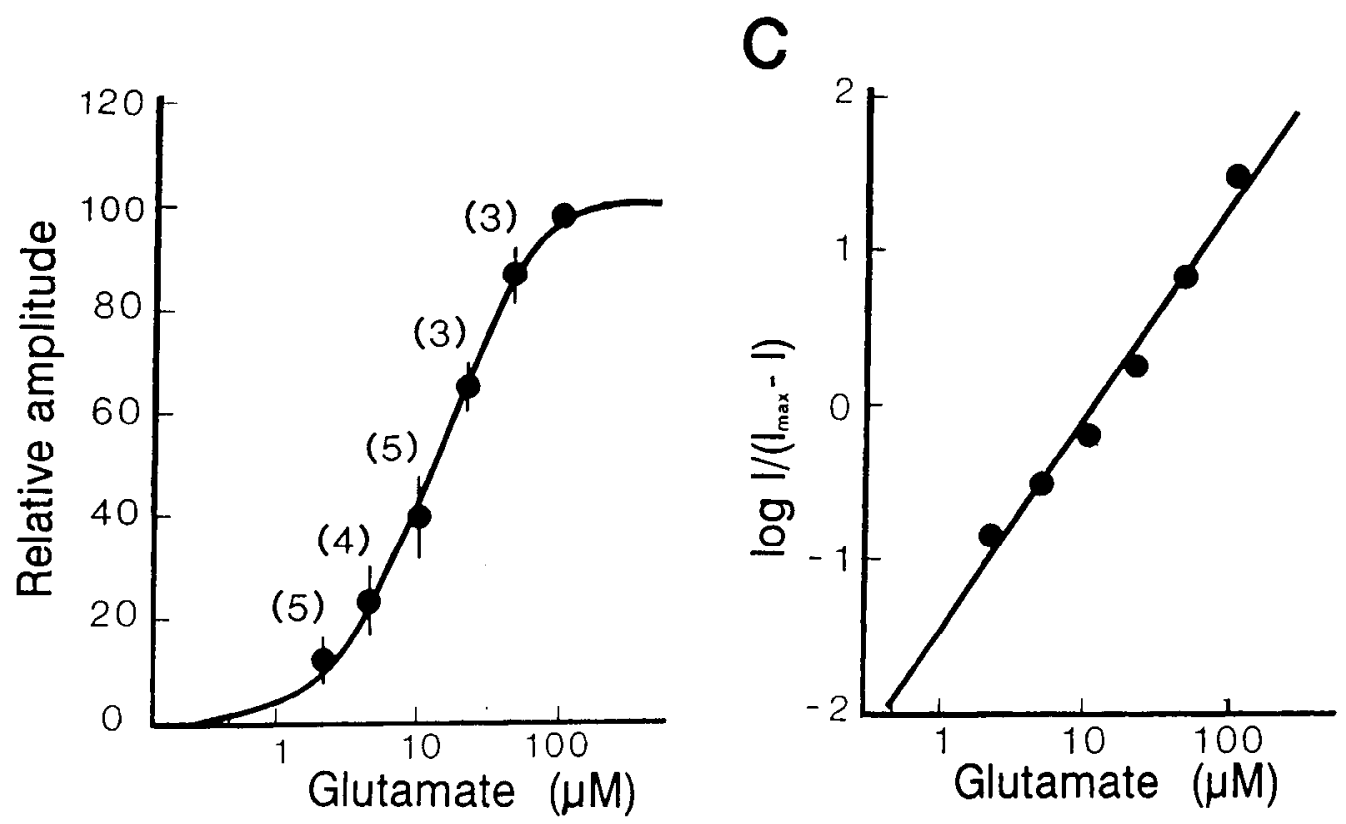

Figure 4. The dose-response relation of Glu in isolated bipolar cells in which Glu induced an outward current response. One hundred micromolar Glu and Glu of test concentrations were pressure applied successively $(A)$ and the response amplitude to the test concentration was normalized to the response amplitude to $100 \mu \mathrm{M}$ Glu. $B$, Normalized and average data (number of samples in parentheses) were plotted against Glu concentration. Short vertical bars represent SD. $C$, Replotting the data in $B$ as a Hill plot. 

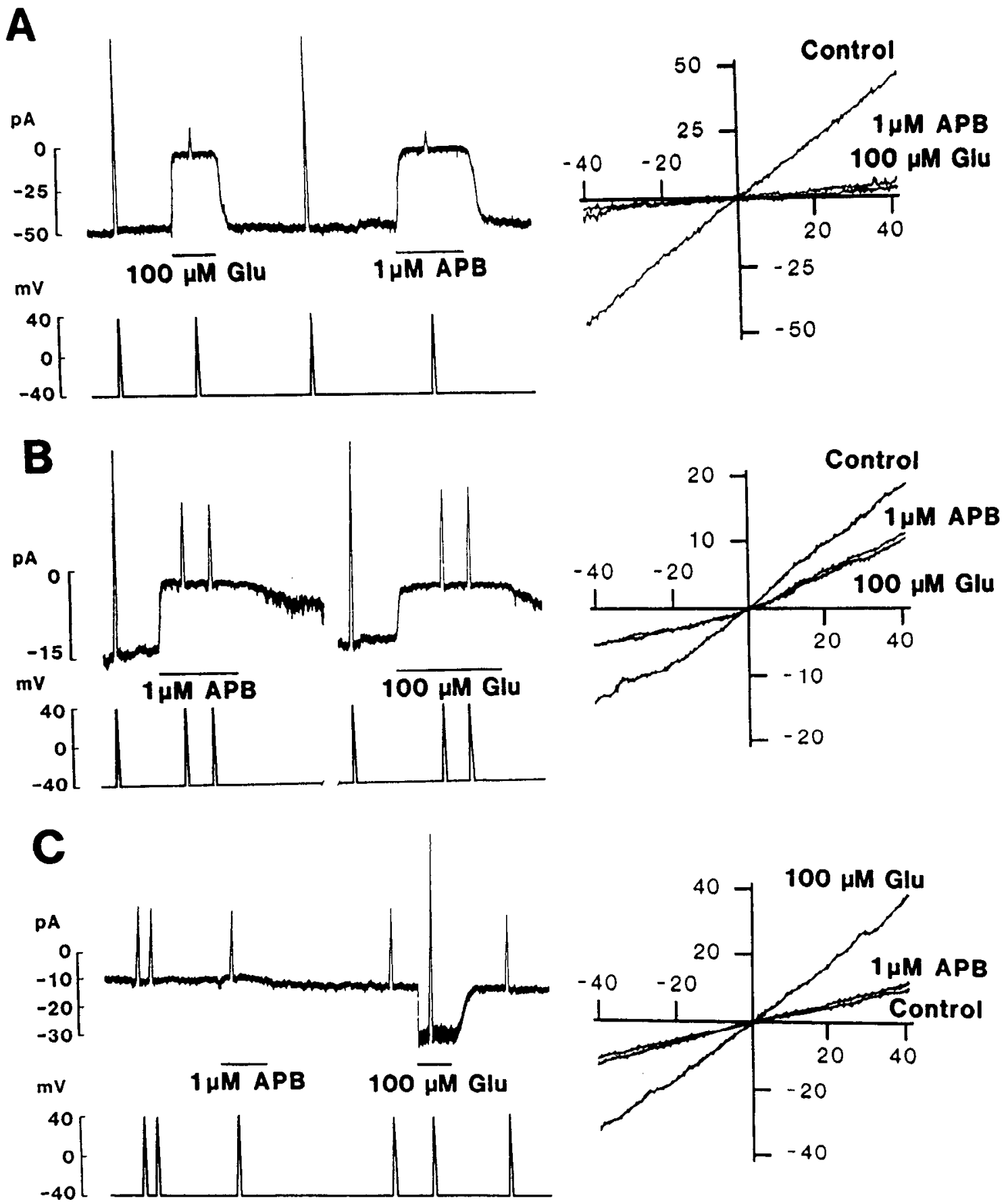

$20 \mathrm{sec}$

Figure 5. Responses to $100 \mu \mathrm{M}$ Glu and to $1 \mu \mathrm{M}$ APB. A, A record obtained from a cell showing positive PKC-IR. Application of both Glu and APB induced an outward current. The cell was voltage clamped at $-40 \mathrm{mV}$ and a ramp depolarization and repolarization (between -40 and +40 $\mathrm{mV}$ at a speed of $160 \mathrm{mV} / \mathrm{sec}$, lower trace) were applied in a control solution and during application of either Glu or APB. Note that the slope of the $I-V$ curve (right panel) became less steep during the application of both Glu and APB, suggesting a conductance decrease. $B$, A recording obtained from a cone bipolar cell showing no PKC-IR. Application of both Glu and APB also induced an outward current. Recordings are continuous but were interrupted by a $120 \mathrm{sec}$ interval between APB application and Glu application. Ramp depolarization revealed that during application of either Glu or APB the slope of the $I-V$ curve (right panel) became less steep, suggesting a conductance decrease. Slow response recovery (e.g., slower than that of $A$ ) was caused by a slow superfusion of the cell sitting in the periphery of the culture dish. $C$, A recording from another cone bipolar cell showing no PKC-IR. Application of Glu induced an inward current, while APB was ineffective. Ramp depolarization revealed that during application of Glu the slope of the $I-V$ curve (right panel) became steeper, suggesting a conductance increase. 
a

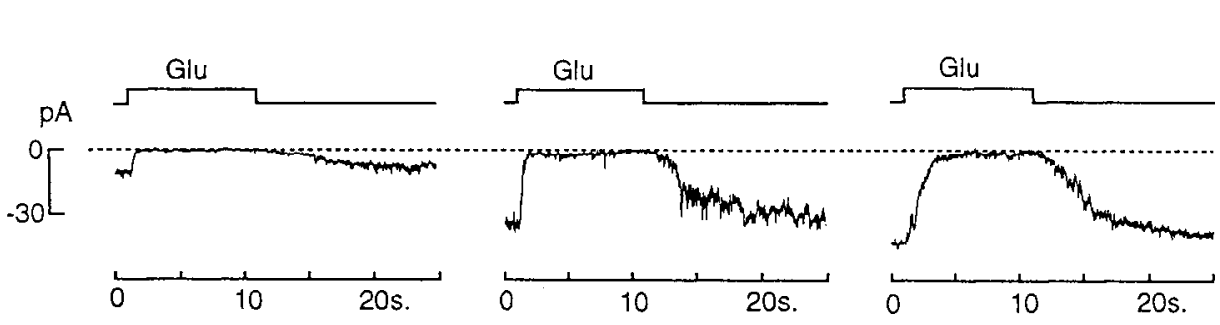

C b (+Glu)

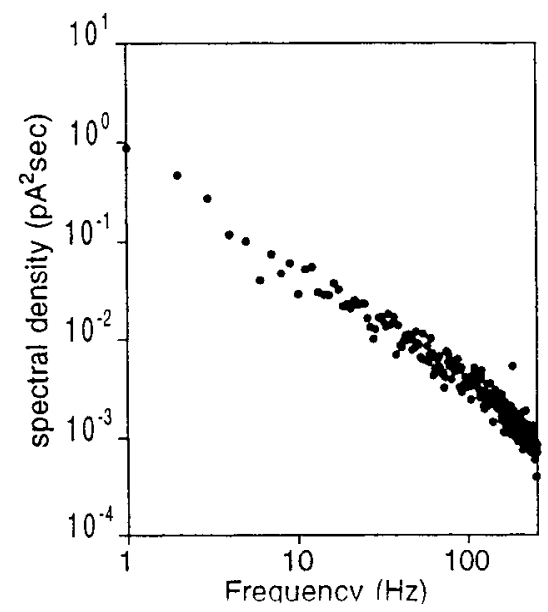

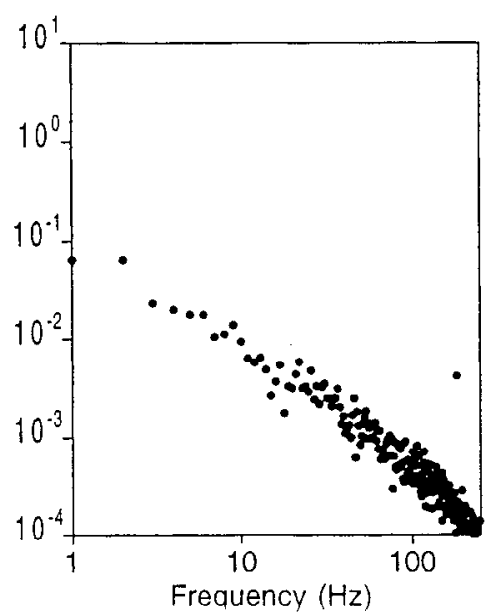

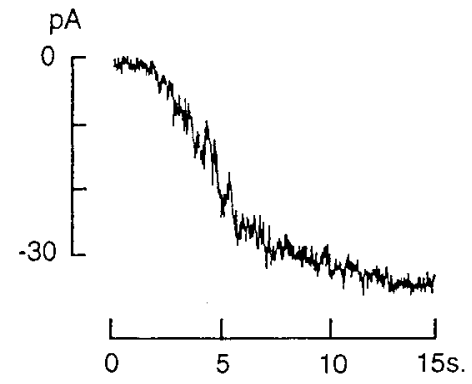

$c(a-b)$

Figure 6. Current fluctuations of the cGMP-activated channel in an ON-type bipolar cell. A, Glu (100 $\mu$ M) was applied by pressure indicated by upward deflections of the top trace. Records were obtained circa $16(a), 18(b)$, and 20 min after the establishment of whole-cell recording configuration. Note that the fluctuations of the steady current increase and then decrease with the increase in the current amplitude. Holding potential, $-40 \mathrm{mV}$. Sampled at $100 \mathrm{~Hz}$ after low-pass filtering by an eight-pole Butterworth filter (cutoff frequency, $50 \mathrm{~Hz}$ ). $B$, Dependence of the current fluctuations on the current amplitude. The falling phase of the trace $A c$ was reproduced in expanded time and amplitude scales. Note that the current fluctuations increase and then decrease as the inward current increases. $C$, Power density spectra of the Glu-suppressive current. Data were sampled in the absence ( $a$, immediately before the response represented at $A b$ ) and the presence of $100 \mu \mathrm{M}$ Glu (during response $A b$ ). The power spectrum of the Glu-suppressive current (identical to the cGMP-activated current) was obtained by subtracting the frequency components in $b$ from those of $a$, and is represented in $c$. The continuous curve represents the sum of two Lorentzian functions fitted by the least squares method. Corner frequencies of the low and high components are 1.3 and $47 \mathrm{~Hz}$, respectively. Data were sampled at $500 \mathrm{~Hz}$ after low-pass filtering by an eight-pole Butterworth filter (cutoff frequency, $250 \mathrm{~Hz}$ ).

open probability. The maximum open probability was approximately $96 \%$. Similar results were obtained in four other cells.

The single channel conductance can be obtained from the relation between $\sigma^{2} / I$ and $I$ :

$$
\sigma^{2} / I=i-I / N
$$

This function depends linearly on $I$. The intercept with the ordinate corresponds to the amplitude of the single channel current (arrowhead in Fig. 7B), and the slope corresponds to the inverse of the number of channels $(1 / N)$. By this method, the amplitude of the single channel current was estimated to be $0.5 \pm 0.1 \mathrm{pA}$ ( $n=5$ ) at $-40 \mathrm{mV}$, giving a single channel conductance of 12.5 $\pm 2.5 \mathrm{pS}$. A similar value has been reported for a Glu-sensitive channel in axolotl ON-type bipolar cells (Attwell et al., 1987). The total number of cGMP-activated channels in an isolated bipolar cell was estimated to be $125 \pm 12$.

\section{Discussion}

In the present study, we demonstrated that isolated bipolar cells dissociated from the cat retina can be classified into two types according to the polarity of the Glu-induced response: the majority of cells responded with an outward current and a small group of cells responded with an inward current. Since photoreceptors release Glu tonically in the dark and the release is suppressed by light, it is expected that Glu generates an outward current in (and thus hyperpolarizes) ON-type bipolar cells and an inward current in (and thus depolarizes) OFF-type bipolar cells. Thus, it is probable that isolated bipolar cells that responded to Glu with an outward current are ON-type cells, and that cells that responded to Glu with an inward current are OFF-type cells. The above identification agrees with several characteristics of ON- and OFF-type bipolar cells. First, the fraction of cells responding to Glu with an outward current (approximately 90\%) agrees with the fraction of rod bipolar cells of the cat retina (cf. 

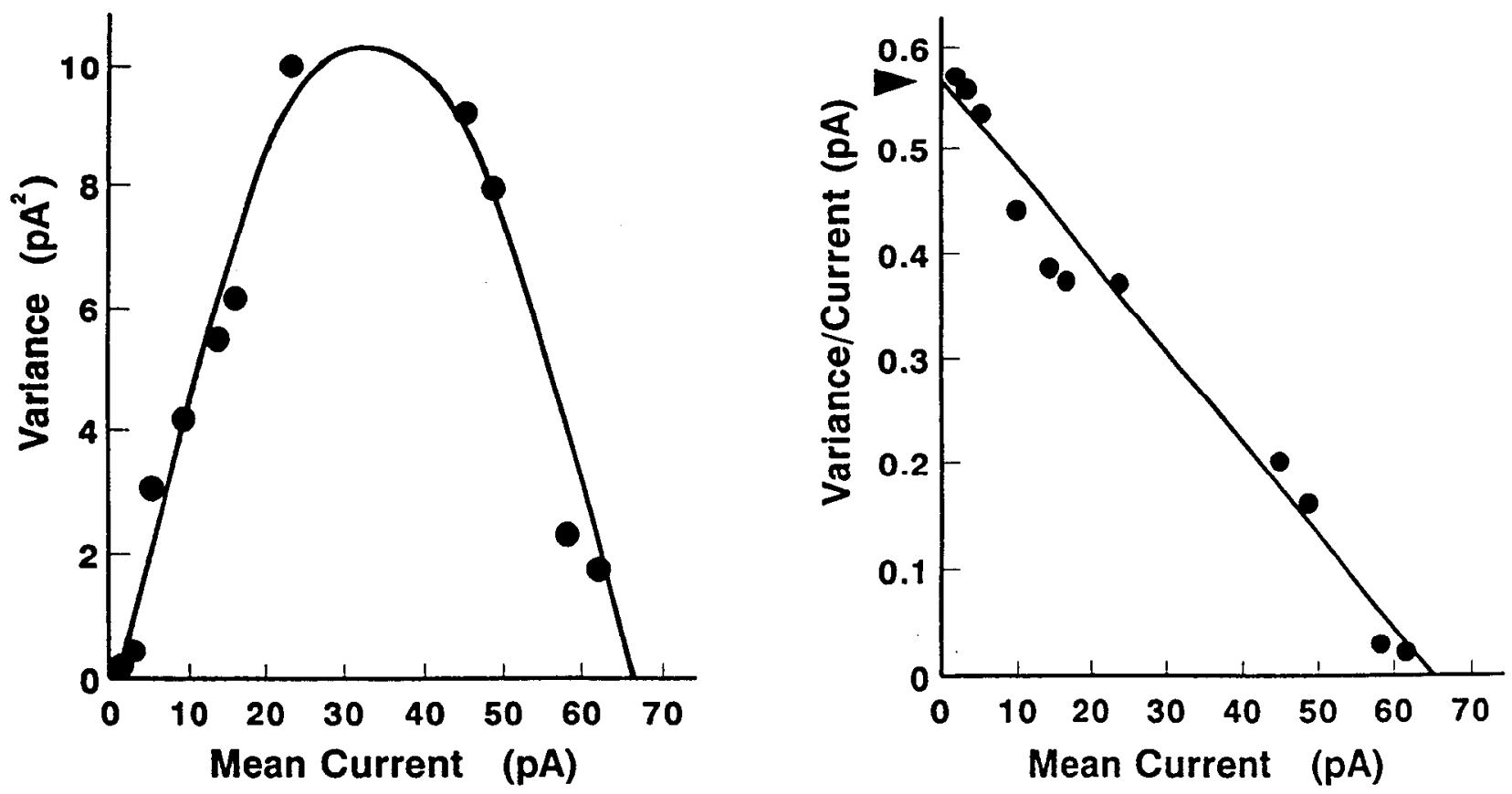

Figure 7. Analysis of the fluctuations of the cyclic GMP-induced current in a bipolar cell in which Glu induced an outward current (a cell different from Fig. 6). A, Relation between variance $\left(\sigma^{2}\right)$ and mean current (I). Variance was calculated during brief $(0.1$ sec) samples of current at different times during the development of the inward current. Basal variance obtained at the complete suppression of current by Glu was subtracted. The continuous line indicates a parabola drawn by the formula $\sigma^{2}=i I-I^{2} / N$, where $N$ represents the total number of cGMP-activated channels and $i$ represents the single channel amplitude. $N$ and $i$ were obtained from the least squares method shown in $B$. $B$, Relation between variance/current $\left(\sigma^{2} / I\right)$ and the current $(I)$ from data show in $A$. The straight line was drawn by the least squares method, with the formula $\sigma^{2} / I=i-I / N$. Parameters: $i, 0.57 \mathrm{pA} ; N, 123$.

Dacheux and Raviola, 1986). Second, the time course of the light-evoked responses of ON-type bipolar cells are known to be slower than those of OFF-type bipolar cells (Copenhagen et al., 1983). The time course of the Glu-induced outward current was much slower than that of the Glu-induced inward current. Third, APB is known to act as a Glu agonist to ON-type bipolar cells, but not to OFF-type bipolar cells. In the present study, we found that APB is a Glu agonist to bipolar cells in which Glu induced an outward current, but was ineffective to cells in which Glu induced an inward current. It is inferred from these observations that the Glu receptor molecules in ON-type bipolar cells are different from those in OFF-type bipolar cells.

It has been suggested in the lower vertebrate that the rod bipolar cell and the ON-type cone bipolar cell have different types of glutamate receptors (Saito et al., 1978; Nawy and Copenhagen, 1987; Hirano and MacLeish, 1990). In the rod bipolar cell, Glu reduces the conductance of cation-permeable channels, while in the ON-type cone bipolar cell, Glu increases the potassium conductance (Saito et al, 1978; Hirano and MacLeish, 1990). It has been reported that APB is a glutamate agonist for rod bipolar cells in the dogfish (Shiells et al., 1981), while it is ineffective to cone-driven ON pathways in the goldfish (DeMarco at al., 1991). In the present study, however, we found that Glu responses in both rod and cone ON-type bipolar cells are essentially the same. First, the response in both types of cells is generated by the decrease of membrane conductance. Second, the underlying ionic channels are activated by cytoplasmic cGMP. Third, cGMP-activated channels in both types of cells have reversal potentials near $0 \mathrm{mV}$, suggesting both are nonselective cation channels. Fourth, APB is effective for both rod and cone ON-type bipolar cells. In the present study we did not find any sign of Glu-induced conductance increase to $\mathrm{K}^{+}$(see also Nawy and Jahr, 1990a; Shiells and Falk, 1990, 1992a,b). Technical difficulties limited our studies on single channel properties to unidentified bipolar cells, but the aforementioned pharmacological and electrophysiological data suggest that Glu transduction systems in rod ON- and cone ON-type bipolar cells are identical.

The Glu-induced outward current in cat bipolar cells was driven by an APB-sensitive Glu receptor and mediated by cytoplasmic cGMP as in bipolar cells of the lower vertebrates (Nawy and Jahr, 1990a, 1991; Shiells and Falk, 1990). Perhaps the receptor molecule mediating the Glu action in ON-type bipolar cells is one of the metabotropic Glu receptors (mGluR6) that have been cloned recently (Nakajima et al., 1993). The signal of Glu binding to the receptor is transferred to a G-protein, which is then coupled to a phosphodiesterase (PDE) (Nawy and Jahr, 1990a, 1991; Shiells and Falk, 1990, 1992a,b). 'This scheme is similar to the transducin-mediated activation of PDE in the photoreceptor outer segment (for revicw, scc, c.g., Pugh and Lamb, 1993). Consistent with this, immunoreactivity against antibodies specific for a particular species of G-protein, different from transducin, has been recently localized in a subset of bipolar cells of the mammalian retina (Vardi et al., 1993).

Yamashita and Wässle (1991) have reported a Glu-induced outward current in rat bipolar cells using a nystatin-perforated 
patch technique. Their observations were similar to our present data in that the Glu suppressed a steady inward current. They suggested, however, that cytoplasmic $\mathrm{Ca}^{2+}$ is essential for the generation of Glu responses. Our interpretation does not agree with theirs since under our whole-cell recording conditions the cytoplasm should have been dialyzed with a Ca-EGTA buffer resulting in a low concentration of cytoplasmic $\mathrm{Ca}^{2+}$.

The introduction of cGMP into ON-type bipolar cells caused the development of an inward current which is suppressed by Glu. This result is consistent with the idea that light-induced depolarization in these cells is generated by an increase in the membrane conductance by the reduction of Glu release from photoreceptor cells. It is expected that ON-type bipolar cells have an intrinsic cGMP pool which induces a standing inward current. Indeed, a standing inward current has been recorded in ON-type bipolar cells in a slice preparation (Nawy and Jahr, 1990b). The standing current diminishes with time when the patch pipette does not contain cGMP or GTP, due perhaps to "washout" of cGMP by internal dialysis. In the present study the standing inward current obtained at the beginning of recording was as small as a few pA, suggesting that the intrinsic cGMP pool in our preparation was very small. It has also been reported in rod bipolar cells isolated from the rat that an APB-suppressible standing inward current is observed in a very small fraction of cells (5/93; Karschin and Wässle, 1990).

The most likely interpretation for the discrepancy between the slice and dissociated preparations is that the intrinsic cGMP level became extremely low by dissociation. Since bipolar cells receive the synaptic input at the dendritic terminal, it could be possible that the guanylyl cyclase is localized to the dendritic iip. If the dissociation treatment lowered the cGMP production by amputating the dendritic tip (see also Karschin and Wässle, 1990), the cGMP pool will soon be depleted by a continuous hydrolysis by an intrinsic phosphodiesterase. With the same reason, the number of cGMP-activated channels calculated here could underestimate the real number present in an ON-type bipolar cell in situ.

The development of the steady inward current by cGMP was slow. A similar time course was observed in a slice preparation (Nawy and Jahr, 1990a). Interestingly, once the inward current had developed, withdrawal of Glu produced an increase of the current to the same preagonist level within $2 \mathrm{sec}$, much faster than the initial current development (see also Nawy and Jahr, 1990a). A possible interpretation is that cGMP supplied from patch pipette into the cytoplasm may be trapped by a high-affinity, large capacity binding mechanism similar to that reported for the rod outer segment (cf. Pugh and Lamb, 1993). Before the development of the steady inward current, the binding sites must be filled with cGMP supplied from the recording pipette. Application of Glu may lower the cGMP concentration only in the vicinity of the plasma membrane. Therefore, upon recovery from the current suppression by Glu, cGMP will be rapidly refilled either from the cytoplasmic storage or from the recording pipette.

In the present study, the unitary conductance of cGMP-activated channels was estimated to be approximately $13 \mathrm{pS}$. Since the standing inward current (and the accompanying current fluctuations) of cat ON-type bipolar cells developed only after cGMP diffused into the cell interior from the recording pipette, it is highly likely that the fluctuations originated mainly in the cGMP-activated channels. It has been argued that fluctuations of the Glu-suppressive current in axolotl bipolar cells may in- clude additional components representing biochemical events located in the upstream to cGMP metabolism (Wilson, 1994). However, agreement of our data and those $(11 \mathrm{pS})$ of Attwell et al. (1987) indicates that fluctuation originating in the earlier stages of cGMP metabolism may be much smaller than the fluctuation generated by channel transitions.

One remarkable difference between our data and Attwell et al.'s (1987) is the maximum open probability: it was alnost $100 \%$ in the present study, while much less than $50 \%$ in the axolotl. This difference can be simply explained by the fact that Attwell et al. (1987) did not put either cGMP or GTP in their recording pipette.

The cyclic nucleotide-gated channels in both visual and olfactory sensory cells show essentially the same gating properties (for review, see, e.g., Kaupp and Koch, 1992; Menini and Anholt, 1994) and exhibit extremely small unitary conductance (0.1 pS, Fesenko et al., 1985) due presumably to the flickering blockage of open channels by divalent cations (Haynes et al., 1986; Matthews, 1986; Zufall and Firestein, 1993). In contrast, however, in the presence of divalent cations the single channel conductance of Glu-suppressive channels (11 pS, Attwell et al., 1987) and of cGMP-activated channels (13 pS, present study) in bipolar cells was two orders of magnitude larger than the value described for sensory channels. Furthermore, cGMP-activated channels in ON-type bipolar cells showed almost $100 \%$ open probability, which never happens when the channels are subject to flickering block. Indeed, it has been shown in cGMPactivated channels of the rod that the relation between the variance and mean current amplitude shows a linear function up to the saturating cGMP concentration, because their maximum open probabilities are extremely low (Matthews, 1986). Part of the difference between sensory transduction channels and bipolar channels may be explained by the fact that cGMP-activated channels in bipolar cells are quite insensitive to divalent cations (Shiells and Falk, 1992b).

We conclude that CGMP-activated channels in retinal ON-type bipolar cells are remarkably different from those described for photoreceptor or olfactory receptor cells. This finding suggests that the cGMP-activated channel in retinal bipolar cells is a novcl subtypc among cyclic nuclcotidc-activated channcls, or possibly a completely different ionic channel, and therefore explains why an antibody against photoreceptor cGMP-activated channels does not stain bipolar cells (Wässle et al., 1992).

\section{References}

Attwell D, Mobbs P, Tessier-Lavigne M, Wilson M (1987) Neurotransmitter-induced currents in retinal bipolar cells of the axolotl, Ambystoma mexicanum. J Physiol (Lond) 387:125-161

Ayoub GS, Korenbrot JI, Copenhagen DR (1989) Release of endogenous glutamate from isolated cone photoreceptors of the lizard. Neurosci Res [Suppl] 10:S47-S56.

Boycott BB, Kolb H (1973) The connections between bipolar cells and photoreceptors in the retina of the domestic cat. J Comp Neurol 148 : 91-114.

Copenhagen D, Jahr CE (1989) Release of endogenous excitator y amino acid from turtle photoreceptors. Nature 341:536-539.

Copenhagen DR, Ashmore JF, Schnapf JL (1983) Kinetics of synaptic transmission from photoreceptors to horizontal and bipolar cells in the turtle retina. Vision Res 23:363-369.

Dacheux RF, Raviola E (1986) The rod pathway in the rabbit retina: a depolarizing bipolar and amacrine cell. J Neurosci 6:331-345.

DeMarco PJ, Bilotta J, Powers MK (199I) DL-2-amino-4-phosphonobutyric acid does not eliminate "ON" responses in the visual system of goldfish. Proc Natl Acad Sci USA 88:3787-3791

Fesenko EE, Kolesnicov SS, Lyubarsky AL (1985) Induction by cyclic 
GMP of cationic conductance in plasma membrane of retinal rod outer segment. Nature 313:310-313.

Gilbertson TA, Scobey R, Wilson M (1991) Permeation of calcium ions through non-NMDA glutamate chammels in retinal bipolar cells. Science 251:1613-1615.

Greferath U, Grünert U, Wässle H (1990) Rod bipolar cells in the mammalian retina show protein kinase $\mathrm{C}$-like immunoreactivity. J Comp Neurol 301:433-442.

Hamill OP, Marty A, Neher E, Sakmann B, Sigworth FJ (1981) Improved patch-clamp techniques for high-resolution current recording from cells and cell-free membrane patches. Pfluegers Arch 395:85100 .

Haynes LW, Kay AR, Yau K-W (1986) Single cyclic GMP-activated channel activity in excised patches of rod outer segment membrane. Nature 321:66-70.

Hirano AA, MacLeish PR (1990) Glutamate and 2-amino-4-phosphonobutyrate evoke and increase in potassium conductance in retinal bipolar cells. Proc Natl Acad Sci USA 88:805-809.

Ishida AT, Kaneko A, Tachibana M (1984) Responses of solitary retinal horizontal cells from Carassius auratus to $\mathrm{L}$-glutamate and related amino acids. J Physiol (Lond) 348:255-270.

Kaneko A, Tachibana M (1986) Effects of $\gamma$-aminobutyric acid on isolated cone photoreceptors of the turtle retina. J Physiol (Lond) 373: 443-461.

Karschin A, Wässle H (1990) Voltage- and transmitter-gated currents in isolated rod bipolar cells of rat retina. J Neurophysiol 63:860-876.

Kaupp UB, Koch K-W (1992) Role of cGMP and $\mathrm{Ca}^{2+}$ in vertebrate photoreceptor excitation and adaptation. Annu Rev Physiol 54:153175.

Matthews G (1986) Comparison of the light-sensitive and cyclic GMPsensitive conductance of the rod photoreceptor: noise characteristics. J Neurosci 6:2521-2526.

Menini A, Anholt RRH (1994) Cyclic nucleotide-activated channels. In: Endocrinology and metabolism, progress in research and clinical practice, Vol 7, Ion channels and ion transport, structure, function and endocrine regulation (Walsh MF, Foa PP, eds). New York: Springer.

Nakajima Y, Iwakabe H, Akazawa C, Nawa H, Shigemoto R, Mizuno $\mathrm{N}$, Nakanishi S (1993) Molecular characterization of a novel retinal metabotropic glutamate receptor mGluR6 with a high agonist selectivity for L-2-amino-4-phosphonobutylate. J Biol Chem 268:1186811873 .

Nakamura T, Gold GH (1987) A cyclic nucleotide-gated conductance in olfactory receptor cilia. Nature 325:442-444.

Nawy S, Copenhagen DR (1987) Multiple classes of glutamate receptor on depolarizing bipolar cells in retina. Nature 325:56-58.

Nawy S, Jahr CE (1990a) Suppression by glutamate of cGMP-activated conductance in retinal bipolar cells. Nature 346:269-271.

Nawy S, Jahr CE (1990b) Time-dependent reduction of glutamate current in retinal bipolar cells. Neurosci Lett 108:279-283.

Nawy S, Jahr CE (1991) cGMP-gated conductance in retinal bipolar cells is suppressed by the photoreceptor transmitter. Neuron 7:677683.

Negishi K, Kato S, Teranishi T (1988) Dopamine cells and rod bipolar cells contain protein kinase $\mathrm{C}$-like immunoreactivity in some vertebrate retinas. Neurosci Lett 94:247-252.

Nelson R, Famiglietti EV Jr, Kolb H (1978) Intracellular staining reveals different levels of stratification for on- and off-center ganglion cells in cat retina. J Neurophysiol 41:472-483.

Pugh EN Jr, Lamb T (1993) Amplification and kinetics of the activation steps in phototransduction. Biochem Biophys Acta 1141:111-149.

Saito T, Kondo H, Toyoda J (1978) Rod and cone signals in the Oncenter bipolar cell: their different ionic mechanisms. Vision Res 18: 591-595.

Shiells RA, Falk G (1990) Glutamate receptors of rod bipolar cells are linked to a cyclic GMP cascade via a G-protein. Proc R Soc Lond [Biol] 242:91-94.

Shiells RA, Falk G (1992a) The glutamate-receptor linked cGMP cascade of the retinal on-bipolar cells is pertussis and cholera toxinsensitive. Proc R Soc Lond [Biol] 247:17-20.

Shiells RA, Falk G (1992b) Properties of the cGMP-activated channel of retinal on-bipolar cells. Proc R Soc Lond [Biol] 247:21-25.

Shiells RA, Falk G, Naghshineh S (1981) Action of glutamate and aspartate analogues on rod horizontal and bipolar cells. Nature 294: $592-594$.

Sigworth FJ (1980) The variance of sodium current fluctuations at the node of Ranvier. J Physiol (Lond) 307:97-129.

Slaughter MM, Miller RF (1981) 2-Amino-4-phosphonobutyric acid: a new pharmacological tool for retina research. Science 211:182-185.

Suzuki S, Kaneko A (1990) Identification of bipolar cell subtypes by protein kinase $\mathrm{C}$-like immunoreactivity in the goldfish retina. Visual Neurosci 5:233-230.

Suzuki S, Kaneko A (1991) Protein kinase C-like immunoreactivity of the On-type bipolar cells in goldfish and mammalian retinas: a useful criterion for subtype identification of isolated cells. Neurosci Res [Suppl] 15:S107-S115.

Vardi N, Matesic DF, Manning DR, Liebman PA, Sterling P (1993) Identification of a $\mathrm{G}$-protein in depolarizing rod bipolar cell. Visual Neurosci 10:473-478.

Wässle H, Grünert U, Cook NJ, Molday RS (1992) The cGMP-gated channel of rod outer segments is not localized in bipolar cells of the mammalian retina. Neurosci Lett 134:199-202.

Wilson M (1994) Glutamate-gated channels in the outer retina. In: Handbook of membrane channels (Peracchia C, ed), pp 287-302. San Diego: Acadcmic.

Wilson M, Tessier-Lavigne M, Attwell D (1987) Noise analysis predicts at least four states for channels closed by glutamate. Biophys $\mathbf{J}$ 52:955-960

Yamashita M, Wässle H (1991) Responses of rod bipolar cells isolated from the rat retina to the glutamate agonist 2-amino-4-phosphonobutyric acid (APB). J Neurosci 11:2372-2382.

Zufall F, Firestein S (1993) Divalent cations block the cyclic nucleotide-gated channel of olfactory receptor neurons. J Neurophysiol 69: 1758-1768. 